\title{
Taxonomic Note: a Pragmatic Approach to the Nomenclature of Phenotypically Similar Genomic Groups
}

\author{
J. B. URSING, ${ }^{1 *}$ R. A. ROSSELLO-MORA, ${ }^{2}$ E. GARCÍA-VALDÉS, ${ }^{2}$ AND J. LALUCAT ${ }^{2}$ \\ Department of Medical Microbiology, Lund University, Malmö General Hospital, S-20502 Malmö, Sweden, ${ }^{1}$ and \\ Laboratori de Microbiologia, Departament de Biologia Ambiental, Facultat de Ciències, Universitat de les Illes Balears, \\ and Institut d'Estudis Avançats (CSIC-UIB), 07071 Palma de Mallorca, Spain ${ }^{2}$
}

\begin{abstract}
Occasionally, genomic groups (DNA groups, genomic species) that have been delimited by DNA-DNA pairing may be phenotypically so similar that they cannot be differentiated for the time being. In these situations it seems best to allow a nomenspecies to contain more than one genomic group and to refer to genomic groups of a nomenspecies as genomovars.
\end{abstract}

Since the 1970 s, the information obtained by DNA-DNA pairing has been used extensively to delimit bacterial species $(4,5)$. DNA-DNA pairing data reveal discontinuities; groups of closely related strains-referred to as genomic groups or genomic species-seem to be separated from distantly related strains by gaps, most often in the region of 50 to $70 \%$ reassociation and a 5 to $7^{\circ} \mathrm{C}$ difference in thermal stability between homologous and heterologous duplexes. Usually only a few intermediate strains are found. However, apart from the reasonable assumption that the genomic groups are monophyletic, they are purely empirical and they have for the time being little heuristic value.

Many genomic groups correspond to previously existing nomenspecies that were delimited by phenotypic criteria, and many new species have been created successfully with the genomic group as a criterion. Problems arise in the cases in which phenotypic groups of bacteria contain two or more genomic groups.

An obvious practical drawback of the genomic group as a criterion of a bacterial nomenspecies is of course that routine identification of bacteria at present relies on phenotypic data. Descriptions of new species are often based on too few strains to provide a reliable description of the intraspecies variability (3). Moreover, the identification of a strain to a genomic group will be doubtful if an insufficient number of differential phenotypic characteristics separate it from other genomic groups. Correct identification is important for the bacteriologist in the field but also for the systematist because new strains add information about the species. A sufficient number of differentiating characteristics would mean a clear-cut difference from every other species on the basis of at least two properties (1).

Probably most bacteriologists agree that nomenspecies that cannot be safely identified phenotypically should not be cre-

\footnotetext{
* Corresponding author.
}

ated; on the other hand, it would be an advantage if as many genomic groups as possible have a place in the bacterial classification in which the nomenspecies is the fundamental unit. Therefore, it seems best to allow a nomenspecies to contain more than one genomic group, each of which could be referred to as a genomovar, analogous to other subdivisions of the nomenspecies. The term was proposed for genomic groups of Pseudomonas stutzeri by Rosselló et al. (2).

Although the designations of infrasubspecific categories have no standing in the Code of Nomenclature of Bacteria, the term genomovar would be useful because it indicates that a genomic group for the time being is a part of a certain nomenspecies and has to be considered in taxonomic work. When phenotypically delimited, it may be turned into a nomenspecies. As was suggested by Rosselló et al. (2), the genomovars of a species should be numbered; the first genomovar should be the DNA group containing the type strain of the species. Each following genomovar should have a reference strain, which should be available in a culture collection.

\section{REFERENCES}

1. Bascomb, S., S. P. Lapage, M. A. Curtis, and W. R. Willcox. 1973. Identification of bacteria by computer: identification of reference strains. J. Gen. Microbiol. 77:291-315.

2. Rosselló, R., E. García-Valdés, J. Lalucat, and J. Ursing. 1991. Genotypic and phenotypic diversity of Pseudomonas stutzeri. Syst. Appl. Microbiol. 8:124 127.

3. Sneath, P. H. A. 1977. The maintenance of large numbers of strains of microorganisms, and the implications for culture collections. FEMS Microbiol. Lett. 1:333-334.

4. Stackebrandt, E., and B. M. Goebel. 1994. Taxonomic note: a place for DNA-DNA reassociation and 16S rRNA sequence analysis in the present species definition in bacteriology. Int. J. Syst. Bacteriol. 44:646-649.

5. Wayne, L. G., D. J. Brenner, R. R. Colwell, P. A. D. Grimont, O. Kandler, M. I. Krichevsky, L. H. Moore, W. E. C. Moore, R. G. E. Murray, E. Stackebrandt, M. P. Starr, and H. G. Trüper. 1987. Report of the Ad Hoc Committee on Reconciliation of Approaches to Bacterial Systematics. Int. J. Syst. Bacteriol. 37:463-464. 